\title{
Ultrasound-guided Erector Spinae Plane Block for postoperative analgesia: A Meta-Analysis of Randomized Controlled Trials
}

\section{Jiao Huang}

Guangxi Medical University First Affiliated Hospital

Jing Chen Liu ( $\sim$ jingchenl@sina.com )

Guangxi Medical University First Affiliated Hospital

\section{Research article}

Keywords: Erector Spinae Plane Block (ESPB), postoperative analgesia, regional blockade, opioid, pain score

Posted Date: March 26th, 2020

DOI: https://doi.org/10.21203/rs.2.22941/v2

License: (c) (i) This work is licensed under a Creative Commons Attribution 4.0 International License. Read Full License

Version of Record: A version of this preprint was published at BMC Anesthesiology on April 14th, 2020. See the published version at https://doi.org/10.1186/s12871-020-00999-8. 


\section{Abstract}

Background Ultrasound-guided Erector Spinae Plane Block (ESPB) has been increasingly applied in patients for postoperative analgesia. Its safety and effectiveness remain uncertain. This meta-analysis aimed to determine the clinical safety and efficacy of ultrasound-guided ESPB in adults undergoing general anesthesia (GA) surgeries.

Methods A systematic databases search was conducted in PubMed, Embase, and the Cochrane Library for randomized controlled trials (RCTs) comparing ESPB with control or placebo. Primary outcome was iv. opioid consumption $24 \mathrm{~h}$ after surgery. Standardized mean differences (SMDs) or risk ratios (RRs) with 95\% confidence intervals (Cls) were calculated with a random-effects model.

Results A total of 11 RCTs consisting of 540 patients were included. Ultrasound -guided ESPB showed a reduction of iv. opioid consumption $24 \mathrm{~h}$ after surgery (SMD $=-2.15 ; 95 \%$ confidence interval $(\mathrm{Cl})-2.76$ to $-1.5, \mathrm{p}<0.00001)$, pain scores at 1 st hour ( $S M D=-0.97 ; 95 \% \mathrm{Cl}-1.84$ to $-0.1, \mathrm{p}=0.03)$ and pain scores at 6 th hour (SMD $=-0.64,95 \% \mathrm{Cl}-1.05$ to $-0.23, p=0.002)$, Also, it lessened the number of patients who required postoperative analgesia ( $R R=0.41,95 \% \mathrm{Cl} 0.25$ to $0.66, p=0,0002)$ and time to first rescue analgesia $(\mathrm{SMD}=4.56,95 \% \mathrm{Cl} 1.89$ to $7.22, \mathrm{p}=0.0008)$. Differences were not significant with the pain score at 12 th hour,24th hour and postoperative nausea and vomiting (PONV).

Conclusions Ultrasound-guided ESPB provides postoperative analgesic efficacy in adults undergoing GA surgeries with no increase in PONV.

\section{Background}

Ultrasound-guided Erector Spinae Plane Block (ESPB) is a novel regional anesthesia technique that local anesthetic $\llbracket L A \rrbracket$ injection is performed into the fascial plane situated between the transverse process of the vertebra and the erector spinae muscles it is considered a relatively safe simple technique to perform.[1, 2] Followed by first description by Forero et al.[1] in 2016, it has been demonstrated successfully to provide analgesia in thoracic and thoracoabdominal surgeries[3,4] However, the use of ultrasound-guided ESPB remained controversial. Recently, several randomized controlled trials (RCTs) [5-7] on this topic have been published, but the determine conclusions cannot be established owing to the modest sample size of these RCTs. We therefore conducted a meta-analysis to examine the efficacy of ultrasound-guided ESPB among adults undergoing general anesthesia (GA) surgery. Our primary outcome was intravenous opioid consumption $24 \mathrm{~h}$ after surgery. Secondly outcomes included pain scores, number of patients who need rescue analgesia, time to first rescue analgesic and postoperative nausea or vomiting (PONV).

\section{Methods}

\section{Literature search and selection Criteria}


This systematic review and meta-analysis of RCTs was reported abiding by the Preferred Reporting Items for Systematic Reviews and Meta Analyses (PRISMA) statement[8] and it was conducted base on the statement of the Cochrane Handbook for Systematic Reviews of Interventions[9]. No formal protocol was registered for this meta-analysis.

PubMed, EMBASE, and the Cochrane Library were searched from inception to August 2019 with no language restriction. The search terms used were:('erector spinae plan block' OR 'erector spinae block' OR 'erector spinae plan blocks' OR 'erector spinae blocks'). The bibliographies of included trials were also manually searched for any eligible trials missed by the electronic search. This process was conducted iteratively until no extra reference could be verified.

Two of us independently performed the preliminary data search, after removing duplicate references, the titles and abstracts were screening for the eligible trials. We included all RCTs in adults who were undergoing GA surgery with the intervention of ultrasound-guided ESPB Trials were excluded for the following criteria: animal or cadaveric studies; reviews; did not report opioid consumption or pain scores as an outcome; Any discrepancies were resolved by discussion with coauthors.

\section{Data extraction and quality assessment}

Data collection was performed by two authors (JH and JCL). The following information was collected from each eligible trial: first author, publication year, patient number, patient characteristics, American Society of Anesthesiologists (ASA) physical status, surgical procedure, ESPB group (position, dosage and concentration), control group (placebo or no invention). Extracted data were entered into a predefined standardized Excel (Microsoft 6 Corporation, USA) file.. For continuous data, we calculated mean and SD, if not provided, median and interquartile range were seen as means and standard deviation(SD) approximately as follows: the median was considered equal to the mean, and the SD was calculated as the interquartile range divided by $1.35[10]$. Any uncertainty arose were figured out though a consensus achieved.

Two authors ( $\mathrm{JH}$ and $\mathrm{JCL}$ ) evaluated the methodological quality of the trials according to the Cochrane risk-of-bias tool[11]. Each item was categorized as having a 'low', 'unclear', or 'high' risk of bias. Any uncertainty arose were resolve by discussion between two researches until a consensus was achieved.

\section{Statistical Analysis}

The relative risks (RRs) and standardized mean differences (SMDs) with 95\% confidence intervals (Cls) were calculated. A random effects model was selected to acquire the most conservative effects estimate. An $I^{2}$ statistic of $25 \%-50 \%$ were defined as low heterogeneity, an $I^{2}$ statistic of $50 \%-75 \%$ were described as moderate heterogeneity, and those with an $\mathrm{I}^{2}$ statistic of $>75 \%$ were considered as high heterogeneity[12], The heterogeneity was substantial when an $I^{2}$ value was over $50 \%$. Subgroup analysis was conducted based on additional analgesia (patient-controlled analgesia device (PCA) versus not PCA) . Publication bias was evaluated using funnel plots. Statistical analyses were calculated using the Review Manager Version 5.3 (Nordic Cochrane Centre, Cochrane Collaboration) 


\section{Results}

\section{Study identification and characteristics}

A total of 675 studies were obtained by the literature search. One further citations were found by hand searching. 212 records were excluded for duplicate studies and a further 448 records removed by screening titles and abstracts. 16 full text publications remained were scrutinized for conclusive identified. 4 of them were excluded because 2 did not report data of interest[13,14], one was currently ongoing study[15],one was review article[16].Finally, 12 RCT[5-7, 17-25] satisfied our inclusion criteria. A flowchart of the literature search is shown in囚Fig. 1区.

All RCTs included in this meta-analysis were published between 2018 and 2019, with a total of 490. The main characteristics of the 12 RCTs included are presented in Table 1.

\section{Primary outcomes}

All RCTs[5-7,17-25] reported data on intravenous opioid consumption $24 \mathrm{~h}$ after surgery . Pooled analysis showed that ultrasound-guided ESPB was associated with a reduction of opioid $24 \mathrm{~h}$ after surgery $(-2.18$, $95 \% \mathrm{Cl}-2.76$ to $-1.61 ; \mathrm{P}<.00001 ;$ Fig2). Substantial heterogeneity was observed among these studies ( $\mathrm{P}$ for heterogeneity<.00001; $\left.\right|^{2}=87 \%$ ). The finding was consistent in subgroup analysis. (Fig. 3 )

\section{Secondary outcomes}

Ultrasound-guided ESPB significantly decrease pain scores at the $1 \mathrm{~h}(-0.80,95 \% \mathrm{Cl}-1.54$ to -0.06 ; ) and 6 $\mathrm{h}[-0.64,95 \% \mathrm{Cl}-0.99$ to -0.30 ;).Furthermore, No. need rescue analgesia $(0.41,95 \% \mathrm{Cl} 0.25$ to $0.66 ; \mathrm{P}=.0002$, $\left.1^{2}=67 \%\right)$ was lower in the ESPB group and time to first rescue analgesic ( $4.56,95 \% \mathrm{Cl} 1.89$ to 7.22$)$ was longer in the ESPB group .Pain scores at $12 \mathrm{~h}, 24 \mathrm{~h}$ after surgery and PONV did not achieve statistical significant significance. All outcomes of the identified trials are reported in Table 2.

\section{Quality assessment and publication bias}

Four trials at a low risk of bias, and 8 trials at an unclear risk of bias. The randomisation procedure was adequately generated in 11 trials [5-7, 17-20,22-25]. Since we subjectively judge the outcome measurement was little prone to be changed by lacking of blinding, all RCTs included were classified as low risk of bias at blinding of outcome assessments. Assessment of risk-of-bias summary of all RCTs are presented in (Fig.4). There was no evidence of publication bias by inspection of the funnel plot(Fig.5)

\section{Discussion}

\section{Main finding}

The main finding of this meta-analysis is that ultrasound-guided ESPB significantly reduced opioid consumption 24 hours after surgery. It further reduced pain scores and patients who need rescue 
analgesia, besides, it prolonged the time to first request of rescue analgesia. Despite of the high heterogeneity, the main finding was consistent in subgroup analyses.

\section{Possible mechanisms for findings}

Ultrasound-guided ESPB is a peri-paravertebral regional anesthesia technique which is supposed to block the dorsal and ventral rami of the thoracic and abdominal spinal nerves [1], and thereby to block the anterior, posterior, and lateral thoracic and abdominal walls. However, the mechanisms of action and spread of LA are not fully elucidated. Several potential mechanisms have been posited. one of the suggested mechanisms of ultrasound-guided ESPB is paravertebral spread of LA, LA infiltration was observed from injection site to three vertebral levels cranially and four levels caudally [26]. Based on this mechanism, Coşarcan SK et al.[27] reported a modification ESPB and got good pain relief in various surgeries. However, the mechanism of paravertebral spread of LA remained debated in several cadaveric studies[28-30]. Another potential mechanism is epidural spread of LA. Schwartzmann A et al [31], Tulgar S, et al[32] and Altıparmak B, et al[33]found unilateral erector spinae plane block result in bilateral sensory blockade in some patients, epidural spread of the LA during ESPB may explain this result. Moreover, some evidence indicated that penetration of LA acted on dorsal and ventral rami through the connective tissues and branch communication leaded to visceral analgesia [34,35]

\section{Implications for clinical researches}

Our findings demonstrated that ultrasound-guided ESPB was associated with a reduction of opioid consumption, which further proved the effectiveness of ESPB. However, ultrasound-guided ESPB has only been utilized in clinical setting for about three years, several important issues have not been resolved yet. First, the optimal concentration, volume and type of LA in ESPB is not well established. Although 20 and $30 \mathrm{ml}$ of $0.25 \%$ bupivacaine or $0.5 \%$ ropivacaine were recommended[36], concentrations of $0.25-0.5 \%$ bupivacaine $10-20 \mathrm{ml}$ were used in ultrasound-guided ESPB among all 12 RCTs included in this metaanalysis. Is bupivacaine more preferred than ropivacaine? why? We tried to make a judgment but stop by the insufficient evidence. More researches of ultrasound-guided ESPB on concentration, volume, type of LA are necessary. Next, although no complications of ultrasound-guided ESPB have been reported in all included RCTs, risks such as LA toxicity, vascular puncture and pneumothorax still need our attention. Two studies have reported pneumothorax associated with ESPB [37, 38], and Selvi $O$ et al. [39] reported unintended motor block linked to ESPB. More complications may appear as the increased use of ultrasound-guided ESPB in population. Last, compared to other regional block techniques such as transversus abdominis plane block (TAPB), serratus plane block (SPB), and Quadratus Lumborum Block (QLB), is the erector spine block more effective in some operations where the block areas overlap? Several RCTs on these topics published recently but far from achieving convincing conclusions[40-42] 


\section{Strengths and limitations}

Our meta-analysis has several strengths. As far as we know, this is the first meta-analysis to evaluate the efficacy of ultrasound-guided ESPB in adults undergoing GA surgery. Besides, we performed this metaanalysis in compliance with the Cochrane Handbook and the PRISMA statement. Several notable limitations should be considered when interpreting the results. Firstly, the trials included have a modest sample size which could magnify the treatment effect. Secondly, the substantial heterogeneity was observed, one major factor result in heterogeneity is the diversity of surgery types (breast, lumbar spine, hip, abdominal etc). Parietal pain is more prominent in breast and lumbar spine, while visceral pain is the main component of postoperative pain following abdominal surgeries. The use of different types of opioid and supplementary analgesics such as paracetamol $[23,24]$ may also add an extra heterogeneity. Furthermore, owing to all patients were under GA surgeries, sensory blocking could not be evaluated adequately to exclude potential block failures of ESPB. Last, although we conducted a comprehensive literature search, it is hard to rule out the possibility of missing studies.

\section{Conclusion}

In summary, ESPB block provides an effective analgesic in adults. However, the results should be interpreted cautiously since insufficient evidence, although accumulating. Further large-scale RCTs are required to support our results.

\section{Abbreviations}

ESPB: erector Spinae Plane Block; GA: general anesthesia; LA: local anesthetic;

RCTs: randomized controlled trials; PRISMA: Preferred Reporting Items for Systematic Reviews and Meta Analyses; RCTs: American Society of Anesthesiologists;

PONV: postoperative nausea or vomiting RRs: relative risks; SD: standard deviation;

SMDs: confidence intervals (Cls) standardized mean differences; PCA: patient-controlled analgesia device

\section{References}

1. Forero M, Adhikary SD, Lopez H, Tsui C, Chin KJ: The Erector Spinae Plane Block: A Novel Analgesic Technique in Thoracic Neuropathic Pain. Regional anesthesia and pain medicine 2016, 41(5):621627.

2. El-Boghdadly K, Pawa A: The erector spinae plane block: plane and simple. Anaesthesia 2017, 72(4):434-438.

3. Chin KJ, Malhas L, Perlas A: The Erector Spinae Plane Block Provides Visceral Abdominal Analgesia in Bariatric Surgery: A Report of 3 Cases. Regional anesthesia and pain medicine 2017, 42(3):372376. 
4. Bonvicini D, Tagliapietra L, Giacomazzi A, Pizzirani E: Bilateral ultrasound-guided erector spinae plane blocks in breast cancer and reconstruction surgery. Journal of clinical anesthesia 2018, 44:3-4.

5. Tulgar S, Kapakli MS, Senturk O, Selvi O, Serifsoy TE, Ozer Z: Evaluation of ultrasound-guided erector spinae plane block for postoperative analgesia in laparoscopic cholecystectomy: A prospective, randomized, controlled clinical trial. Journal of clinical anesthesia 2018, 49:101-106.

6. Tulgar S, Kose HC, Selvi O, Senturk O, Thomas DT, Ermis MN, Ozer Z: Comparison of UltrasoundGuided Lumbar Erector Spinae Plane Block and Transmuscular Quadratus Lumborum Block for Postoperative Analgesia in Hip and Proximal Femur Surgery: A Prospective Randomized Feasibility Study. Anesthesia, essays and researches 2018, 12(4):825-831.

7. Singh S, Kumar G, Akhileshwar: Ultrasound-guided erector spinae plane block for postoperative analgesia in modified radical mastectomy: A randomised control study. Indian journal of anaesthesia 2019, 63(3):200-204.

8. Moher D, Liberati A, Tetzlaff J, Altman DG: Preferred reporting items for systematic reviews and metaanalyses: the PRISMA statement. Bmj 2009, 339:b2535.

9. Cochrane handbook for systematic reviews of interventions version 5.1.0.

10. Hozo SP, Djulbegovic B, Hozo I: Estimating the mean and variance from the median, range, and the size of a sample. BMC Med Res Methodol 2005, 5:13.

11. Higgins JP, Altman DG, Gotzsche PC, Juni P, Moher D, Oxman AD, Savovic J, Schulz KF, Weeks L, Sterne JA: The Cochrane Collaboration's tool for assessing risk of bias in randomised trials. $\mathrm{Bmj}$ 2011, 343:d5928.

12. Higgins JP, Thompson SG, Deeks JJ, Altman DG: Measuring inconsistency in meta-analyses. Bmj 2003, 327(7414):557-560.

13. Krishna SN, Chauhan S, Bhoi D, Kaushal B, Hasija S, Sangdup T, Bisoi AK: Bilateral Erector Spinae Plane Block for Acute Post-Surgical Pain in Adult Cardiac Surgical Patients: A Randomized Controlled Trial. Journal of cardiothoracic and vascular anesthesia 2019, 33(2):368-375.

14. Macaire P, Ho N, Nguyen T, Nguyen B, Vu V, Quach C, Roques V, Capdevila X: Ultrasound-Guided Continuous Thoracic Erector Spinae Plane Block Within an Enhanced Recovery Program Is Associated with Decreased Opioid Consumption and Improved Patient Postoperative Rehabilitation After Open Cardiac Surgery-A Patient-Matched, Controlled Before-and-After Study. Journal of cardiothoracic and vascular anesthesia 2019, 33(6):1659-1667.

15. Breebaart MB, Van Aken D, De Fre O, Sermeus L, Kamerling N, de Jong L, Michielsen J, Roelant E, Saldien V, Versyck B: A prospective randomized double-blind trial of the efficacy of a bilateral lumbar erector spinae block on the $24 \mathrm{~h}$ morphine consumption after posterior lumbar inter-body fusion surgery. Trials 2019, 20(1):441.

16. Urits I, Charipova K, Gress K, Laughlin P, Orhurhu V, Kaye AD, Viswanath O: Expanding Role of the Erector Spinae Plane Block for Postoperative and Chronic Pain Management. Current pain and headache reports 2019, 23(10):71. 
17. Singh S, Choudhary NK, Lalin D, Verma VK: Bilateral Ultrasound-guided Erector Spinae Plane Block for Postoperative Analgesia in Lumbar Spine Surgery: A Randomized Control Trial. Journal of neurosurgical anesthesiology 2019.

18. Ciftci B, Ekinci M, Celik EC, Tukac IC, Bayrak Y, Atalay YO: Efficacy of an Ultrasound-Guided Erector Spinae Plane Block for Postoperative Analgesia Management After Video-Assisted Thoracic Surgery: A Prospective Randomized Study. Journal of cardiothoracic and vascular anesthesia 2019.

19. Gurkan Y, Aksu C, Kus A, Yorukoglu UH: Erector spinae plane block and thoracic paravertebral block for breast surgery compared to IV-morphine: A randomized controlled trial. Journal of clinical anesthesia 2019, 59:84-88.

20. Hamed MA, Goda AS, Basiony MM, Fargaly OS, Abdelhady MA: Erector spinae plane block for postoperative analgesia in patients undergoing total abdominal hysterectomy: a randomized controlled study original study. Journal of pain research 2019, 12:1393-1398.

21. Yayik AM, Cesur S, Ozturk F, Ahiskalioglu A, Ay AN, Celik EC, Karaavci NC: Postoperative Analgesic Efficacy of the Ultrasound-Guided Erector Spinae Plane Block in Patients Undergoing Lumbar Spinal Decompression Surgery: A Randomized Controlled Study. World Neurosurg 2019, 126:e779-e785.

22. Aksu C, Kuş A, Yörükoğlu HU, Kılıç CT, Gürkan Y: The Effect of Erector Spinae Plane Block on Postoperative Pain Following Laparoscopic Cholecystectomy: A Randomized Controlled Study. JARSS 2019, 27(1):9-14.

23. Gurkan Y, Aksu C, Kus A, Yorukoglu UH, Kilic CT: Ultrasound guided erector spinae plane block reduces postoperative opioid consumption following breast surgery: A randomized controlled study. Journal of clinical anesthesia 2018, 50:65-68.

24. Abu Elyazed MM, Mostafa SF, Abdelghany MS, Eid GM: Ultrasound-Guided Erector Spinae Plane Block in Patients Undergoing Open Epigastric Hernia Repair: A Prospective Randomized Controlled Study. Anesthesia and analgesia 2019, 129(1):235-240.

25. Aksu C, Kus A, Yorukoglu HU, Tor Kilic C, Gurkan Y: Analgesic effect of the bi-level injection erector spinae plane block after breast surgery: A randomized controlled trial. Agri : Agri (Algoloji) Dernegi'nin Yayin organidir $=$ The journal of the Turkish Society of Algology 2019, 31(3):132-137.

26. Chin KJ, Adhikary S, Sarwani N, Forero M: The analgesic efficacy of pre-operative bilateral erector spinae plane (ESP) blocks in patients having ventral hernia repair. Anaesthesia 2017, 72(4):452-460.

27. Cosarcan SK, Gurkan Y, Dogan AT, Ercelen O: Targeted modification of erector spinae plane block. Acta Anaesthesiol Scand 2020, 64(2):276.

28. Ivanusic J, Konishi Y, Barrington MJ: A Cadaveric Study Investigating the Mechanism of Action of Erector Spinae Blockade. Reg Anesth Pain Med 2018, 43(6):567-571.

29. Aponte A, Sala-Blanch X, Prats-Galino A, Masdeu J, Moreno LA, Sermeus LA: Anatomical evaluation of the extent of spread in the erector spinae plane block: a cadaveric study. Can J Anaesth 2019, 66(8):886-893.

30. Yang HM, Choi YJ, Kwon HJ, O J, Cho TH, Kim SH: Comparison of injectate spread and nerve involvement between retrolaminar and erector spinae plane blocks in the thoracic region: a cadaveric 
study. Anaesthesia 2018, 73(10):1244-1250.

31. Schwartzmann A, Peng P, Maciel MA, Forero M: Mechanism of the erector spinae plane block: insights from a magnetic resonance imaging study. Can J Anaesth 2018, 65(10):1165-1166.

32. Tulgar S, Selvi O, Ahiskalioglu A, Ozer Z: Can unilateral erector spinae plane block result in bilateral sensory blockade? Can J Anaesth 2019, 66(8):1001-1002.

33. Altiparmak B, Korkmaz Toker M, Uysal Al: Potential mechanism for bilateral sensory effects after unilateral erector spinae plane blockade in patients undergoing laparoscopic cholecystectomy. Can $J$ Anaesth 2020, 67(1):161-162.

34. Hamilton DL, Manickam B: Erector spinae plane block for pain relief in rib fractures. Br J Anaesth 2017, 118(3):474-475.

35. Adhikary SD, Bernard S, Lopez H, Chin KJ: Erector Spinae Plane Block Versus Retrolaminar Block: A Magnetic Resonance Imaging and Anatomical Study. Reg Anesth Pain Med 2018, 43(7):756-762.

36. Krishnan S, Cascella M: Erector Spinae Plane Block. In: StatPearls. edn. Treasure Island (FL): StatPearls Publishing StatPearls Publishing LLC.; 2020.

37. Ueshima H: Pneumothorax after the erector spinae plane block. J Clin Anesth 2018, 48:12.

38. Hamilton DL: Pneumothorax following erector spinae plane block. J Clin Anesth 2019, 52:17.

39. Selvi O, Tulgar S: Ultrasound guided erector spinae plane block as a cause of unintended motor block. Rev Esp Anestesiol Reanim 2018, 65(10):589-592.

40. Altiparmak B, Korkmaz Toker M, Uysal Al, Kuscu Y, Gumus Demirbilek S: Ultrasound-guided erector spinae plane block versus oblique subcostal transversus abdominis plane block for postoperative analgesia of adult patients undergoing laparoscopic cholecystectomy: Randomized, controlled trial. $J$ Clin Anesth 2019, 57:31-36.

41. Aksu C, Sen MC, Akay MA, Baydemir C, Gurkan Y: Erector Spinae Plane Block vs Quadratus Lumborum Block for pediatric lower abdominal surgery: A double blinded, prospective, and randomized trial. J Clin Anesth 2019, 57:24-28.

42. Gaballah KM, Soltan WA, Bahgat NM: Ultrasound-Guided Serratus Plane Block Versus Erector Spinae Block for Postoperative Analgesia After Video-Assisted Thoracoscopy: A Pilot Randomized Controlled Trial. J Cardiothorac Vasc Anesth 2019, 33(7):1946-1953.

\section{Declarations}

Ethics approval and consent to participate: Not applicable

Consent for publication: Not applicable

Availability of data and materials: Not applicable

Competing interests: The authors declare that they have no competing interests

Funding: Not applicable. 
Authors' contributions: $\mathrm{JH}$ and $\mathrm{JC}$ L participated in the entire procedure including the design and coordination of the study, the literature search, data extraction, performed the statistical analysis, drafted the manuscript, revised submitted the manuscript. All authors read and approved the final manuscript.

Acknowledgements: Not applicable.

\section{Tables}

Table 1. Characteristics of included studies. 


\begin{tabular}{|c|c|c|c|c|c|c|}
\hline $\begin{array}{c}\text { No. Of } \\
\text { patients }\end{array}$ & $\begin{array}{l}\text { Surgical } \\
\text { procedure }\end{array}$ & ASA & $\begin{array}{c}\text { Patient } \\
\text { Characteristics }\end{array}$ & ESPB group & $\begin{array}{l}\text { Control } \\
\text { group }\end{array}$ & GA induction \\
\hline $\begin{array}{l}\text { Tulgar 30(15/15) } \\
2018 \\
(1)\end{array}$ & $\begin{array}{c}\text { Laparoscopic } \\
\text { cholecystectomy }\end{array}$ & प-口 & $\begin{array}{c}\text { 18-65 years } \\
\text { of age }\end{array}$ & $\begin{array}{c}\text { Bilateral } \\
\text { ultrasound-guided } \\
\text { ESPB at the level of } \\
\text { T9 transverse } \\
\text { process } \\
\text { using } 10 \mathrm{~mL} \text { of } \\
\text { bupivacaine } 0.375 \% \\
\text { on each side }\end{array}$ & $\begin{array}{c}\text { Received } \\
\text { no } \\
\text { intervention }\end{array}$ & $\begin{array}{c}\text { Propofol 2- } \\
3 \mathrm{mgkg}-1 \text {,fentanyl100 } \mu \mathrm{g} \\
\text { and rocuronium bromide } \\
0.6 \mathrm{mg} \mathrm{kg}-1\end{array}$ \\
\hline $\begin{array}{l}\text { Gürkan 50(25/25) } \\
2018\end{array}$ & $\begin{array}{l}\text { Elective breast } \\
\text { cancer surgery }\end{array}$ & प- & $\begin{array}{l}\text { Aged 20-65 } \\
\text { years }\end{array}$ & $\begin{array}{l}\text { Ultrasound (US)- } \\
\text { guided } \\
\text { ESPB with } 20 \mathrm{ml} \\
0.25 \% \text { bupivacaine } \\
\text { at the T4 vertebral } \\
\text { level }\end{array}$ & $\begin{array}{l}\text { Received } \\
\text { no } \\
\text { intervention }\end{array}$ & $\begin{array}{c}\text { Propofol(2-3 mg } \\
\mathrm{kg}-1) \text { and fentanyl }(2 \mathrm{mg} \\
\mathrm{kg}-1) \text { iv, rocuronium } \\
0.6 \mathrm{mg} \mathrm{kg}-1\end{array}$ \\
\hline $\begin{array}{l}\text { Tulgar 40(20/20) } \\
2018 \\
\text { (2) }\end{array}$ & $\begin{array}{l}\text { Hip and } \\
\text { proximal } \\
\text { femur } \\
\text { surgery }\end{array}$ & ૧- प & $\begin{array}{l}\text { Aged } \\
18-65 \\
\text { years }\end{array}$ & $\begin{array}{c}\text { Ultrasound-guided } \\
\text { ESPB } \\
\text { at T9 vertebrae } \\
\text { level with } \\
20 \mathrm{ml} \text { bupivacaine } \\
0.5 \% \text {, } \\
10 \mathrm{ml} \text { lidocaine } 2 \% \text {, }\end{array}$ & $\begin{array}{l}\text { Underwent } \\
\text { the } \\
\text { same } \\
\text { procedure } \\
\text { but had no } \\
\text { block }\end{array}$ & $\begin{array}{c}\text { Propofol 2-3mg/kg, } \\
\text { fentanyl } 100 \mu \mathrm{g} \text { and } \\
\text { rocuronium bromide } 0.6 \\
\mathrm{mg} / \mathrm{kg} .\end{array}$ \\
\hline
\end{tabular}

\begin{tabular}{|c|c|c|c|c|c|c|}
\hline $\begin{array}{l}\text { Singh } 40(20 / 20) \\
2019 \\
(1)\end{array}$ & $\begin{array}{l}\text { Elective lumbar } \\
\text { spine surgery }\end{array}$ & प-口 & $\begin{array}{c}\text { 18-65 years } \\
\text { of age }\end{array}$ & $\begin{array}{c}\text { Ultrasound (US)- } \\
\text { guided } \\
\text { ESPB with total } \\
20 \mathrm{ml} 0.5 \% \\
\text { bupivacaine } \\
\text { at the T10 vertebral } \\
\text { level }\end{array}$ & $\begin{array}{l}\text { Received } \\
\text { no } \\
\text { intervention } \\
\text { l }\end{array}$ & $\begin{array}{l}\text { Propofol } 2 \text { to } 3 \mathrm{mg} / \mathrm{kg} \text {, } \\
\text { morphine } 0.1 \mathrm{mg} / \mathrm{kg} \text { and } \\
\text { vecuronium } 0.1 \mathrm{mg} / \mathrm{kg}\end{array}$ \\
\hline $\begin{array}{l}\text { Gürkan 50(25/25) } \\
2019\end{array}$ & $\begin{array}{c}\text { Elective } \\
\text { unilateral } \\
\text { breast surgery }\end{array}$ & प-口 & $\begin{array}{l}\text { Aged 18-65 } \\
\text { years }\end{array}$ & $\begin{array}{l}\text { Ultrasound (US) } \\
\text { guided } \\
\text { ESP block with } 20 \\
\text { ml } \\
0.25 \% \text { bupivacaine } \\
\text { at the T4 vertebral } \\
\text { level }\end{array}$ & $\begin{array}{l}\text { Received } \\
\text { no } \\
\text { intervention }\end{array}$ & $\begin{array}{c}\text { Propofol (2-3 mg kg-1 ) } \\
\text { and fentanyl ( } 2 \mu \mathrm{g} \mathrm{kg}-1 \\
\text { ) iv and rocuronium } 0.6 \\
\text { mg kg-1 }\end{array}$ \\
\hline
\end{tabular}

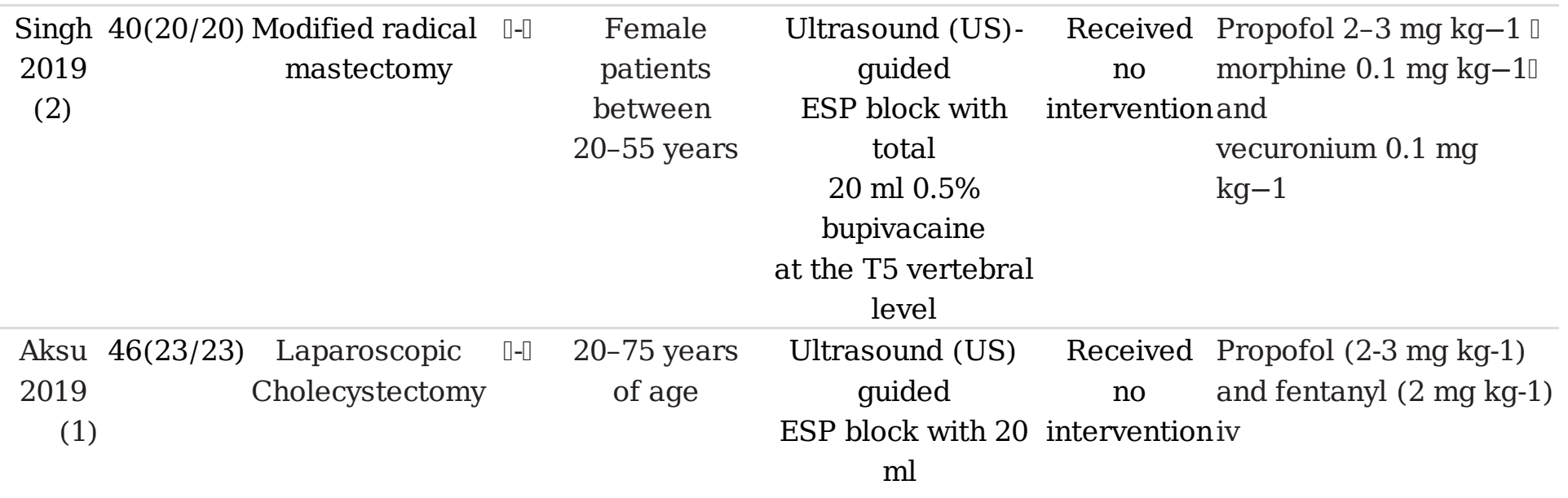


$0.25 \%$ bupivacaine

at the T5-6

vertebral

level

\begin{tabular}{|c|c|c|c|c|c|c|}
\hline $\begin{array}{l}\text { Ciftci } 60(30 / 30) \\
2019\end{array}$ & $\begin{array}{l}\text { Video-Assisted } \\
\text { Thoracic surgery }\end{array}$ & प-口 & $\begin{array}{c}\text { 18-65 years } \\
\text { of age }\end{array}$ & $\begin{array}{c}\text { Ultrasound guided } \\
\text { Bilateral ESP block } \\
\text { with20ml of } \\
0.375 \% \text { bupivacaine } \\
\text { at the T5 } \\
\text { vertebral level }\end{array}$ & $\begin{array}{c}\text { Received } \\
\text { no } \\
\text { interventio }\end{array}$ & $\begin{array}{l}\text { Propofol }(2-2.5 \mathrm{mg} / \mathrm{kg}) \\
\text { and fentanyl }(1-1.5 \\
\mathrm{nmg} / \mathrm{kg}) \\
\text { and rocuronium bromide } \\
\quad(0.6 \mathrm{mg} / \mathrm{kg})\end{array}$ \\
\hline $\begin{array}{l}\text { Ciftci 60(30/30) } \\
2019\end{array}$ & $\begin{array}{l}\text { Video-Assisted } \\
\text { Thoracic surgery }\end{array}$ & प- & $\begin{array}{c}\text { 18-65 years } \\
\text { of age }\end{array}$ & $\begin{array}{l}\text { Ultrasound guided } \\
\text { Bilateral ESP block } \\
\text { with20ml of } \\
\begin{array}{l}0.375 \% \\
\text { bupivacaine } \\
\text { at the T5 } \\
\text { vertebral } \\
\text { level }\end{array}\end{array}$ & $\begin{array}{l}\text { Received } \\
\text { no } \\
\text { interventio }\end{array}$ & $\begin{array}{l}\text { Propofol }(2-2.5 \mathrm{mg} / \mathrm{kg}) \\
\text { and fentanyl }(1-1.5 \\
\mathrm{nmg} / \mathrm{kg}) \\
\text { and rocuronium bromide } \\
\quad(0.6 \mathrm{mg} / \mathrm{kg})\end{array}$ \\
\hline
\end{tabular}

and Rocuronium (0.6 mg kg-1)IV

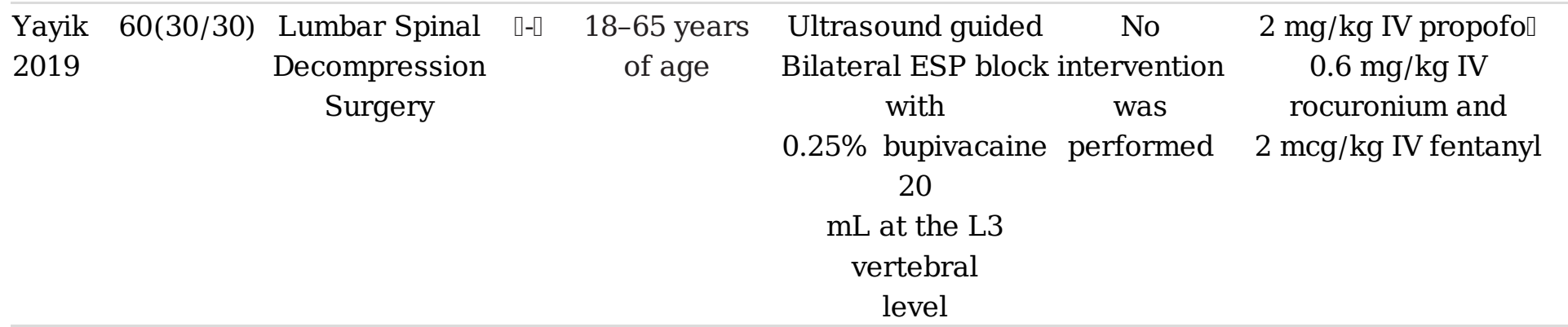

\begin{tabular}{|c|c|c|c|c|c|c|}
\hline $\begin{array}{l}\text { Hamed 60(30/30) } \\
2019\end{array}$ & $\begin{array}{c}\text { Abdominal } \\
\text { hysterectomy }\end{array}$ & प- & $\begin{array}{c}\text { Women } \\
\text { aged } 40-70 \\
\text { years old and } \\
\text { weighed } \\
50-90 \mathrm{~kg}\end{array}$ & $\begin{array}{c}\text { Ultrasound-guided } \\
\text { ESPB } \\
\text { at T9 vertebrae } \\
\text { level with } \\
20 \text { ml bupivacaine } \\
0.5 \% .\end{array}$ & $\begin{array}{l}\text { Underwent } \\
\text { the } \\
\text { same } \\
\text { procedure } \\
\text { but had a } \\
\text { sham } \\
\text { injection } \\
\text { (20 ml of } \\
\text { saline) }\end{array}$ & $\begin{array}{c}\text { Fentanyl } 2 \text { mcg.kg-1 } \\
\text { and propofol } \\
2 \text { mg.kg1, followed by } \\
\text { atracurium } \\
0.5 \text { mg.kg-1 }\end{array}$ \\
\hline $\begin{array}{l}\text { AKSU 50(25/25) } \\
2019 \\
\text { (2) }\end{array}$ & $\begin{array}{c}\text { elective breast } \\
\text { surgery }\end{array}$ & 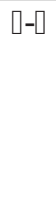 & $\begin{array}{c}\text { Aged between } \\
25 \text { and } 70 \\
\text { years }\end{array}$ & $\begin{array}{c}\text { Ultrasound-guided } \\
\text { ESPB betweenT2 } \\
\text { and T4 with } 10 \mathrm{ml} \\
\text { of } 0.25 \% \\
\text { bupivacaine }\end{array}$ & $\begin{array}{c}\text { No } \\
\text { intervention } \\
\text { was } \\
\text { performed }\end{array}$ & $\begin{array}{c}\text { Propofol (2-3 } \\
\mathrm{mg} / \mathrm{kg}) \text { and fentanyl (2 } \\
\mathrm{mg} / \mathrm{kg}) \text { iv and } \\
\text { Rocuronium } 0.6 \mathrm{mg} / \mathrm{kg} \\
\text { was administered iv }\end{array}$ \\
\hline
\end{tabular}

Table2: Outcome data of RCTs included in the meta-analysis. 


\begin{tabular}{|c|c|c|c|c|c|}
\hline Outcome & $\begin{array}{l}\text { Studies } \\
\text { include }\end{array}$ & $\begin{array}{l}\text { RR or Std.mean } \\
\text { differance } \\
{[95 \% \mathrm{CI}]}\end{array}$ & $\begin{array}{l}\text { P-value for } \\
\text { statistical } \\
\text { significance }\end{array}$ & $\begin{array}{l}\text { P-value for } \\
\text { heterogeneity }\end{array}$ & $\begin{array}{l}\mathrm{I} \square \text { test for } \\
\text { heterogeneity }\end{array}$ \\
\hline $\begin{array}{l}\text { Opiod consumption in the first } 24 \\
\text { hour(mg) }\end{array}$ & 12 & $-2.18[-2.76,-1.61]$ & $<0.00001$ & $<0.00001$ & $87 \%$ \\
\hline VAS/NRS scores at the 1st hour & 6 & $-0.80[-1.54,-0.06]$ & 0.03 & $<0.00001$ & $88 \%$ \\
\hline VAS/NRS scores at the 6th hour & 8 & $-0.64[-0.99,-0.30]$ & 0.0003 & 0.03 & $58 \%$ \\
\hline VAS/NRS scores at the 12th hour & 6 & $-0.16[-0.66,0.33]$ & 0.51 & 0.0008 & $76 \%$ \\
\hline VAS/NRS scores at the 24th hour & 8 & $-0.83[-1.78,0.12]$ & 0.09 & 0.00001 & $94 \%$ \\
\hline Rescue analgesia requirement(n) & 7 & $0.41[0.25,0.66]$ & 0.0002 & 0.006 & $67 \%$ \\
\hline Time to first rescue analgesic(min) & 3 & $4.56[1.89,7.22]$ & 0.0008 & 0.00001 & $95 \%$ \\
\hline $\begin{array}{l}\text { POVN( postoperative nausea and } \\
\text { vomiting ) }\end{array}$ & 9 & $0.45[0.20,1.00]$ & 0.05 & $<0.00001$ & $84 \%$ \\
\hline
\end{tabular}

\section{Figures}




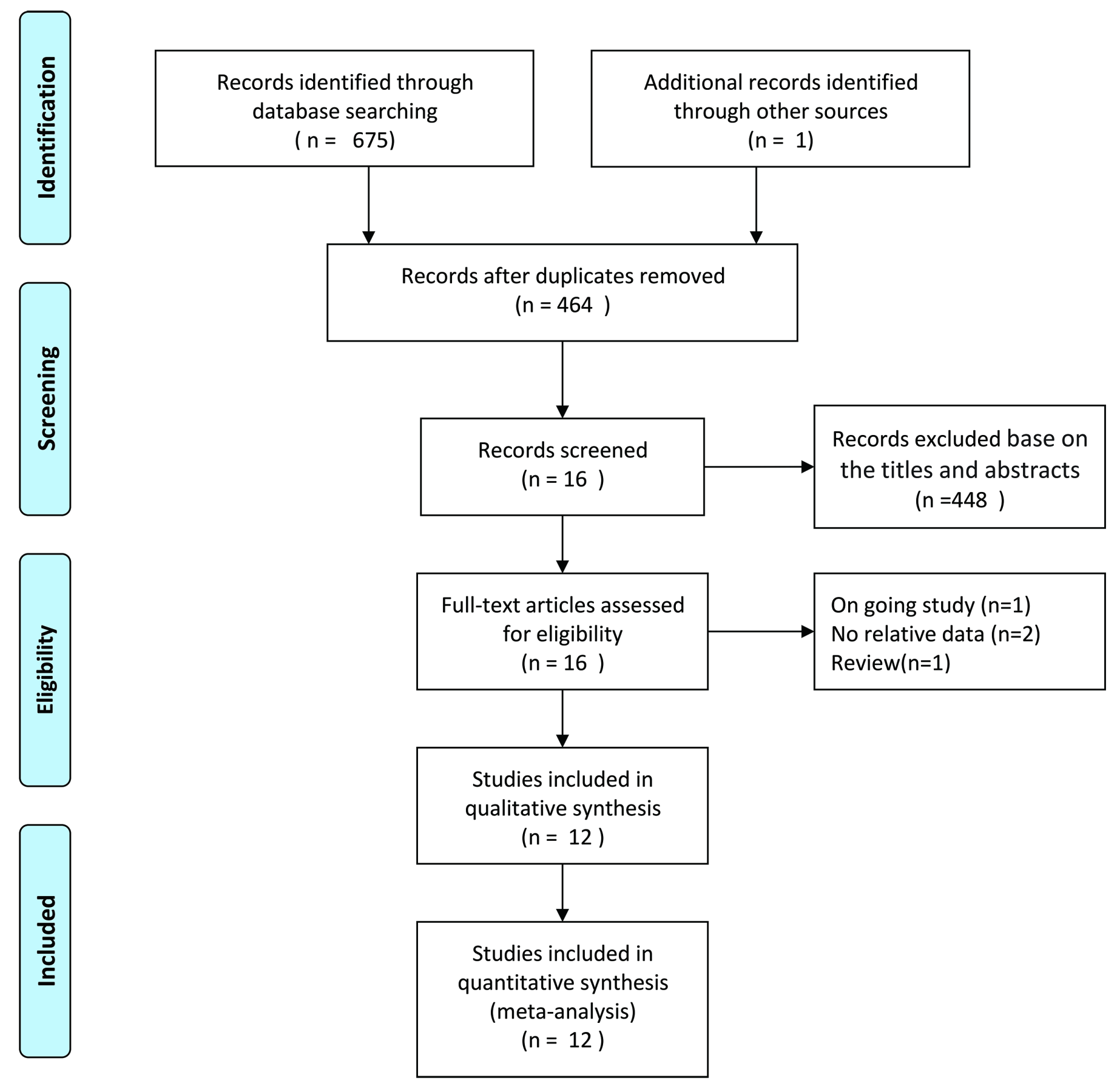

Figure 1

PRISMA flow diagram showing literature search results. 


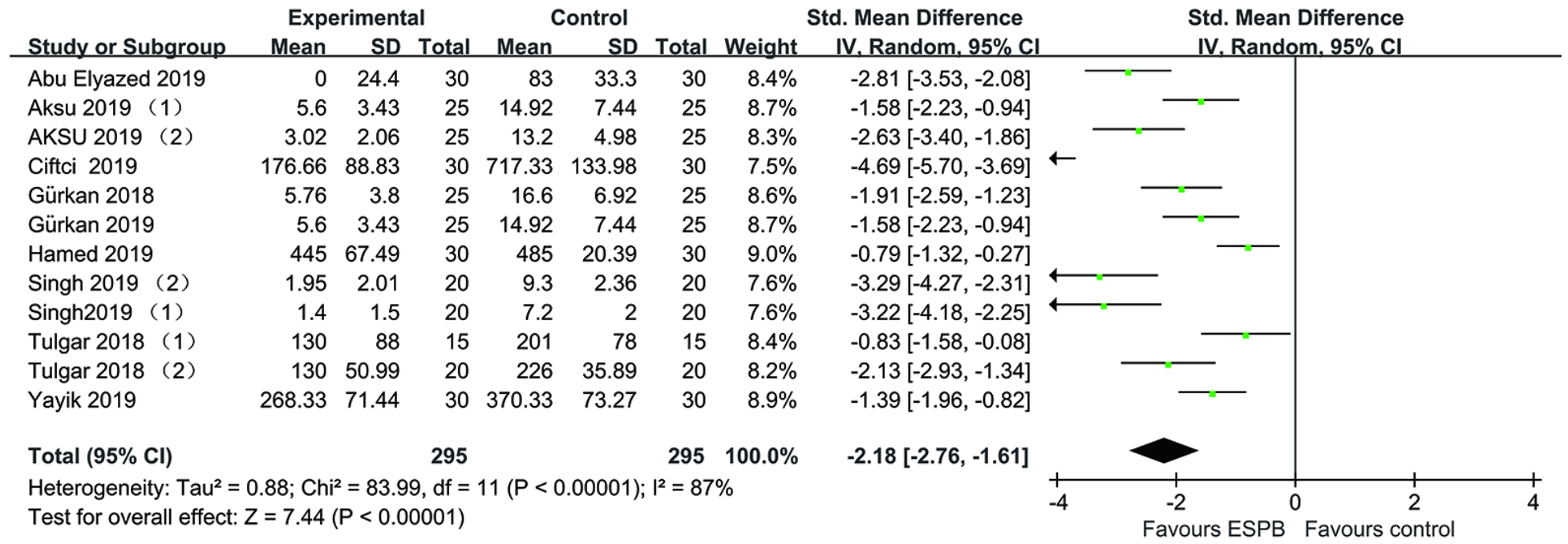

\section{Figure 2}

Forest plots of morphine consumption 24 hour after surgery.

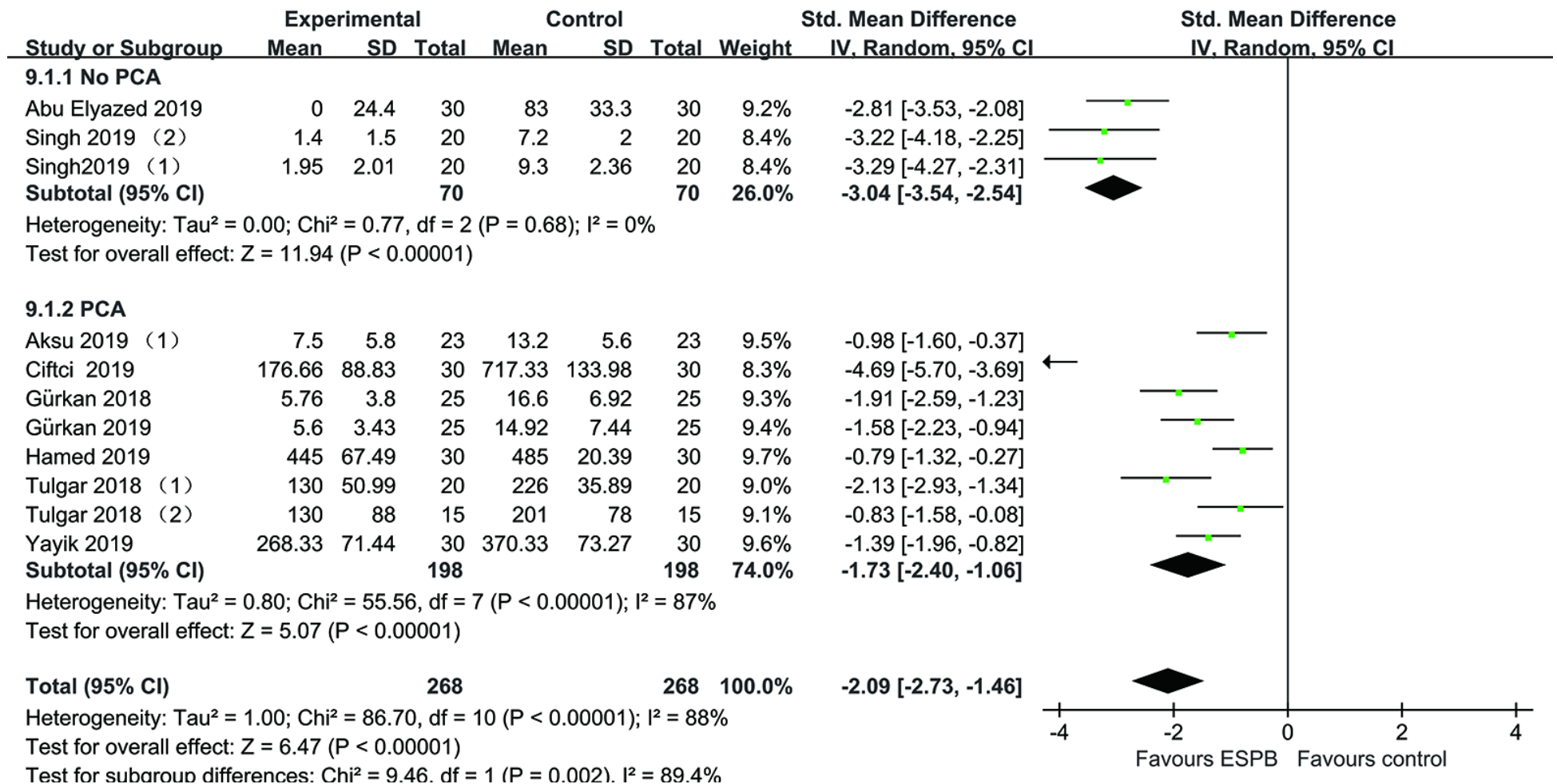

\section{Figure 3}

Forest plots of subgroup analysis. 


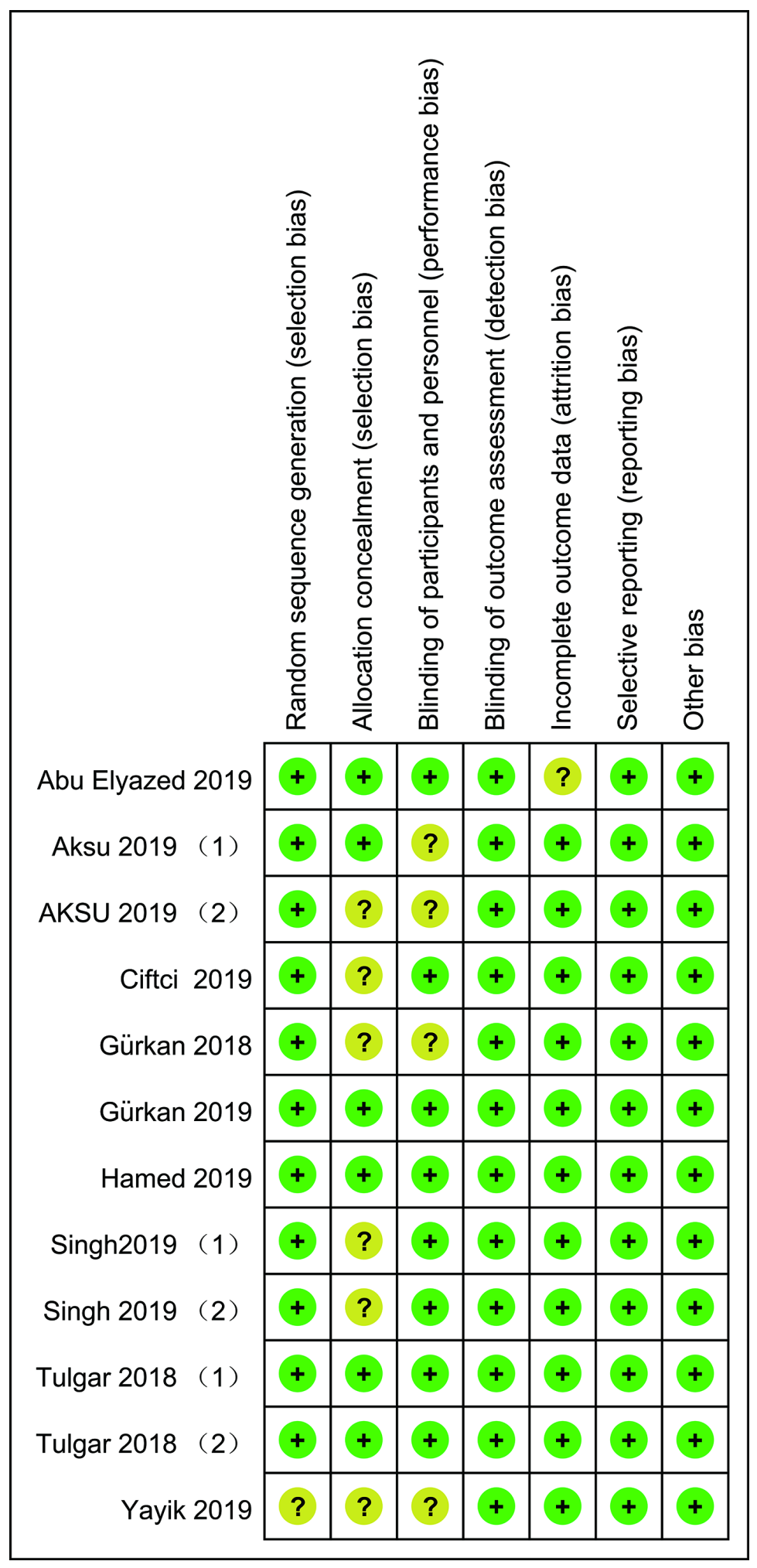

Figure 4

Risk of bias. 


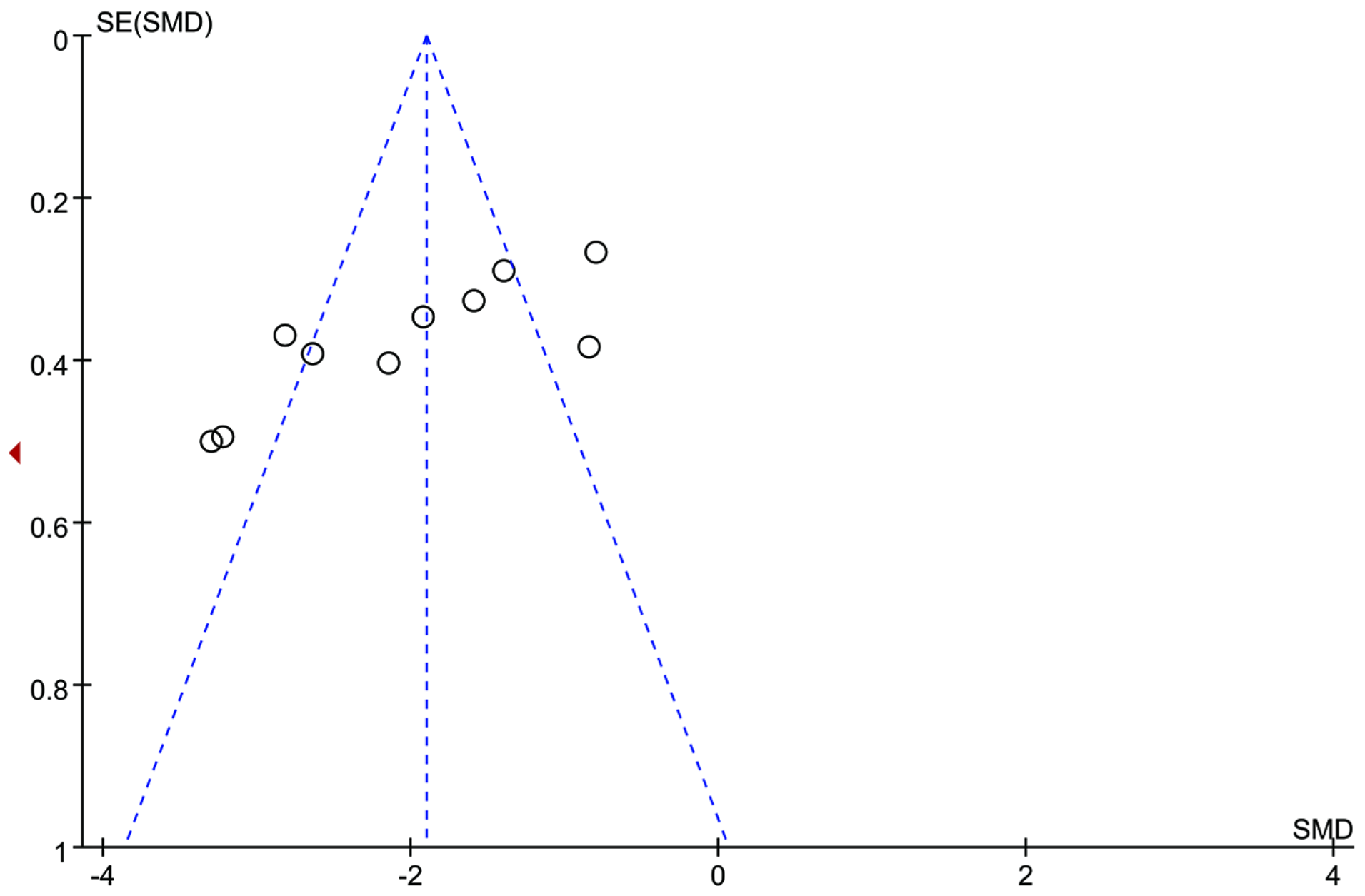

Figure 5

Funnel plot evaluating publication bias.

\section{Supplementary Files}

This is a list of supplementary files associated with this preprint. Click to download.

- PRISMAchecklist.doc 